\title{
LEARNING, BODY AND IERRITORY AMONG INDIGENOUS XAKRIABÁ BOYS
}

\author{
Rogério Correia da Silva* \\ Ana Maria R. Gomes** \\ Universidade Federal de Minas Gerais - Brazil
}

\begin{abstract}
This article draws on an ethnographical study of indigenous Xakriabá boys, focusing on fieldwork that explores everyday practices that characterise the passage from domestic space to manhood through territory circulation. The hunt assumes an emblematic position in the learning process configuration that constitutes the male ethos of the Xakriabá. We review the unique arrangement of key practices, exploring their articulations and revealing learning processes developed both through the use of the scythe in agricultural work, and through hunting in the woods that surround the villages. Learning is explored as an inherent dimension of social practices. We highlight the relationships among different learning configurations in order to identify recurrent themes, such as peer interaction and co-responsability, which characterise particular ways of learning among the Xakriabá.
\end{abstract}

Keywords: agricultural work, hunting, indigenous Xakriabá boys, learning.

Resumo: $O$ artigo retoma a etnografia realizada com os meninos do povo indígena Xakriabá e focaliza cenas de campo que descrevem práticas presentes no cotidiano desses meninos que caracterizam a passagem do espaço doméstico para o mundo adulto masculino através da circulação pelo território. A caça assume um lugar emblemático na configuração das aprendizagens que constituem o ethos masculino dos Xakriabá. A configuração singular de tais práticas é revisitada para explorar suas articulações e revelar as aprendizagens que se tornam possíveis no uso da foice, parte do trabalho na roça; e na caça, realizada na mata do entorno das aldeias. Explorase a aprendizagem como dimensão inerente às práticas e busca-se estabelecer relações entre as configurações de diferentes aprendizagens para explicitar orientações

* Contact: rogex.correia@gmail.com.

** Contact: anarabelogomes.bhz@gmail.com.

Horizontes Antropológicos, Porto Alegre, ano 21, n. 44, p. 173-200, jul./dez. 2015 http://dx.doi.org/10.1590/S0104-71832015000200008 
recorrentes como a interação entre pares e a cor-responsabilização na condução das práticas, que revelam modos de aprender próprios nas interações entre os Xakriabá.

Palavras-chave: aprendizagem, caça, meninos indígenas xakriabá, trabalho na roça.

In this essay, we will explore some of the learning processes that mark the passage of Xakriabá boys from the confined world of the family to free movement within their people's territory, which lies to the North of Minas Gerais, near the city of São João das Missões. We will focus on two specific examples that allow us to explore and discuss the way Xakriabá boys come of age. One example centres on the notion of the person, involving commensality and kinship production; boys work in the crop fields (roça) with their relatives, learning particular tasks assigned to boys in a context where all activities are part of a set of actions that involve commensality and kinship networks. The other example involves gender attributes, which will be examined in connection with hunting and learning to hunt. This paper also explores encounters with supernatural beings that the boys must learn to deal with. These encounters take place while the boys are roaming across their territory. In considering each topic, this paper will focus on key practices involved in the boys' upbringing, ${ }^{1}$ which reveal nuances of the Xakriabá way of learning. Revisiting the two themes derived from our study of the Xakriabá boys (Correa, 2013; Silva, 2011) raises important questions about learning and its relationship with culture. In both farming and hunting, the boys' relationship with Xakriabá territory is strongly thematised, while their involvement in both situations emphasises their developed bodies and ability to move skilfully in whatever context they find themselves.

Starting from this point, we will explore the theme of learned cultural practices through the experience of the Xakriabá boys, although the topic has ramifications far beyond their particular situation. By focusing on this group,

\footnotetext{
1 These themes, developed by combining PhD fieldwork (Silva, 2011) with a monograph written an indigenous student (Correa, 2013), were presented at the Intercultural Formation for Indigenous Educators, a teacher training course. It would also be worth exploring the gap between these themes and the path that leads boys out of their villages, bringing them into contact with the outside world and everything it involves, such as mobile phones and computers, as well as complex topics such as weapons and drugs. Another issue that could not be addressed in this article involves the importance of 'storytelling', especially when learning to hunt.
}

Horizontes Antropológicos, Porto Alegre, ano 21, n. 44, p. 173-200, jul./dez. 2015 
we suggest that this approach may be a way to re-elaborate canonical formulations of learning, while acknowledging Jean Lave's assertion (Lave, 2011) of the need to review the assumptions that guide such research. We are driven by agents and contexts that regard other conceptions of learning as 'invading schools' (cf. Cohn; Tassinari, 2009; Gomes, 2006; Weber, 2006), rather than being influenced by concepts from within schooling. Observing the practices of the Xakriabá allows us to analyse particular aspects of their way of learning. This approach is based on an idea of learning as changing participation in practices (Lave; Wenger, 1991); our goal is to identify a possible ethnographic theory of learning (cf. Goldman, 2006) through these practices.

The Xakriabá Indigenous Land (TIX, in Portuguese) is located in the city of São João das Missões, in the far north of Minas Gerais, a place that has been referred to in historical documents since the beginning of the $18^{\text {th }}$ century as São João dos Índios. A written document certifies that this land is owned by the indigenous people, as it was given to them by Januário Cardoso in 1728 . When the Land Law was enacted in 1850, this document was resubmitted to reconfirm possession. The region was gradually taken over by colonial expansion. According to a map that depicts the different ethnic groups occupying this land around the donation period, from the second half of the $19^{\text {th }}$ century to the beginning of the $20^{\text {th }}$, the presence of this indigenous group is already registered as unique in the region (cf. Santos, R. M., 2013). Despite ancient and irrefutable documentation, TIX was only ratified in 1987, after disputes that resulted in the death of one of the region's leaders (cf. Santos, A. F. M., 1997). For two centuries, the region where TIX stands today absorbed groups of people from many different backgrounds. Newcomers were welcomed by many TIX leaders, none of whom attempted to dominate or impose centralised rule on the territory. This approach created a diversified spectrum of populations in a wide range of settings, across thirty villages (cf. Santos, R. B. C., 2010). The period following land ratification was relatively stable, involving few conflicts with the outside world and a certain calming of internal disputes. This led to sharp population growth, as recorded in many works (Gomes; Monte-Mór, 2005; Pena, 2004). Between 2004 and 2005, over 60\% of the population was under 20 years of age. Nowadays, the region has approximately 9,000 people.

This brief historical and political overview reveals a scenario that, since the establishment of the missionary settlement (missões) and its closure at the beginning of the $18^{\text {th }}$ century, has always combined internal and external 
elements: initially, there were land ownership negotiations, reaffirmed to the colonial authorities in 1850. An institutional framework was established during the "FUNAI initial period", with the National Indian Foundation (FUNAI) acting as a state guardianship agency till 1988 (when, with the new Brazilian Constitution, indigenous became full citizens); followed by their autonomous political participation in the formation of the new municipality during the 1990s. Today, this is the only municipality to have had an indigenous administration for the last three terms of office. All public figures are male; the role of women in this environment needs to be better documented and analysed. Their role is particularly important to understand, given that most men leave TIX to work in the agricultural fields, mainly to grow sugarcane for below minimum wages. This $20^{\text {th }}$ century migration has taken place since the 1960 s, becoming more intense between the 1970s and 1990s (cf. Gomes; Monte-Mór, 2005; Teixeira, 2008). In some villages, $90 \%$ of the male population is absent for most of the year.

This picture has been changing since intensive schooling began in 1995. Based on a program conforming to the requirements of the Law of Guidelines and Bases for National Education n. 9394/1996, indigenous schools were built in Minas Gerais; since 1997, only indigenous teachers have been hired to teach in these institutions. These teachers have prepared for the job by taking the first teachers' training course in secondary level education (cf. Pereira, 2013). Currently, the Xakriabá have over 130 undergraduate teachers with Intercultural Indigenous Educators' Training degrees, as well as many student teachers enrolled in a variety of undergraduate courses at several institutes of higher education. In fact, as one 16-year-old girl commented during the MG/ES Indigenous Women's Meeting, modern young people no longer consider going to town to seek employment in private homes or working in crop fields. They know that it is possible to go to universities and they prefer to stay in their village schools, preparing themselves for the future. ${ }^{2}$

Although both girls and boys take part in intensive schooling, ${ }^{3}$ we focus here on the dynamics involving boys. This choice is based on recent research

\footnotetext{
2 Meeting organised by FUNAI-Governador Valadares, for indigenous women from Minas Gerais (MG) and Espírito Santo (ES) held in Aldeia Verde Maxakali, the city of Ladainha (MG), on the $27^{\text {th }}, 28^{\text {th }}$ and $29^{\text {th }}$ of November 2014.

3 According to Teixeira (2008), data from the period between 2005 and 2008 shows the increased presence of girls in Xakriabá schools, suggesting a pattern that follows the worldwide trend: a greater percentage of women having access to education. However, because of programs developed during the past six years, the latest table includes numbers that have not yet been checked. The demographics of a reduced
} 
findings, showing that Xakriabá boys still prepare themselves to become men by moving around the indigenous territory (cf. Correa, 2013; Silva, 2011). These investigations describe the different contexts of participation that characterise the lives of Xakriabá boys. Hunting practice and, more broadly, the boys' experience of freely and skilfully navigating their territory, are the activities that really distinguish the birth of the male ethos. A boy makes the transition from his original family home, a domain dominated by women, to moving freely through his relatives' households and the territory as a whole, with access to all of its different pathways and routes, especially in the woods.

In analysing the learning processes that characterise the upbringing of the Xakriabá boy, we will focus on the period just before the start of migration tension; we will not study the migration process itself. ${ }^{4}$ In addition, we will not analyse the learning process that occurs a little later, when the boys start to participate in meetings as 'watchmen' (vigilantes, cf. Escobar, 2012). These meetings are local opportunities to negotiate collective interests and actualise power relations, both internal and external. It is a ritualised and codified moment in which linguistic abilities are entangled with social relations.

\section{The male activities of working in the crop fields (roca) and learning how to use the scythe (bater foice)}

'Don't you work with any of your relatives?', a Xakriabá boy asked Rafael Santos, who was doing research in the Barreiro village. The boy was surprised to discover that none of the people Santos worked with were relatives (Santos, R. B. C., 2010, p. 50). The boy's amusing surprise reflects an important concept, which Xakriabá children learn at a very early age: everything you do in life, including socializing and working, is done with relatives. The idea of being part of a community of relatives is a feature of everyday

population, although significant in the case of indigenous populations, can change dramatically in a relatively short period of time. Unfortunately, we still lack the instruments and studies needed to fully explore these movements and their implications.

${ }^{4}$ It is worth considering a scene described by Teixeira (2008). A 13-year-old boy waits without falling asleep, for fear of being late for the truck that will come at dawn to take him to the tomato fields near TIX. His work lasts the entire day. The boy returns at dusk and receives less than 3 reais per harvest box collected. Like all workers, he has to provide his own meal.

Horizontes Antropológicos, Porto Alegre, ano 21, n. 44, p. 173-200, jul./dez. 2015 
group activities, including conversation, working in the crop fields, participating in festive events, becoming a godfather, eating together, conducting weddings, and educating children. A group much larger than the nuclear family is always involved in these activities.

The exchange and/or sharing of food is an important part of this kinship network and the basis of the local economy. These exchanges and interactions reveal the means by which the group continuously updates its kinship ties in the course of everyday life. United in life and in eating together (União na vida e na comidaria) is a well-known saying among the Xakriabá, expressing very well their commensality and kinship ties. It marks the importance of food as a sociability principle made visible through family exchanges, generating strong social bonds. These bonds emerge through product exchange, and are also expressed when people eat together, eating from the same pot; both activities are conducted with great generosity, and even prodigality.

During their first years, indigenous boys and girls devote themselves to life within the family group and inside the female household environment, which is exclusively dedicated to the provision of nourishment and healthcare. Young children spend the entire day inside and around the house. After waking in the morning, they feed themselves, play, carry out household chores, bathe, and go back to sleep. Part of these children's daily relationship with peers and adults inside the house involves joining other groups and learning the tasks and responsibilities they will have to take on throughout their lives. The educational process develops through everyday actions that have a powerful influence over the bodies of boys and girls, ultimately shaping and changing them in accordance with the community's personhood ideals.

Except when they are hunting, boys do not roam freely inside the territory; instead, they are restricted to carrying out daily activities within village limits; they go to school, herd cattle, and carry out field chores. This study will analyse hunting as well as the work carried out in crop fields; in particular, we will examine the use of a very common farming tool, the scythe. When boys reach eight years of age, the so-called guys (rapazinhos) gradually move away from the female house environment, as well as from the care and chores of women, in order to master the tasks allocated to men.

There are many steps involved in working on crop fields and producing food. The first task is to plan and prepare the ground for planting by clearing (limpa) the land. This is carried out by various groups and organizations, 
including single family and larger groups on a rotating basis that implies service exchange. ${ }^{5}$ Decisions regarding where and with whom to plant, the size of the crop field, and the crops to be planted are made at this moment. In addition to hoes, axes and scythes are the tools most needed at this stage. This is also the time for initiating 'coivara', a traditional farming technique that involves burning native vegetation, followed by a rotation of crops.

Other steps follow the clearing of land: planting, weeding, harvesting, and collecting seeds. Then the whole process begins again. Work is carried out throughout the year in accordance with the time each crop needs to grow; intensely productive periods alternate with less active ones. The cycles of rain and drought guide the agricultural production process.

Although work in the Xakriabá crop fields is identified as a male activity, we found women and children also taking part. However, we noticed something peculiar about this shared work. Even when men and women work together on certain tasks, such as weeding or harvesting, some tasks become more specific to groups of men. In addition, boys start learning how to make fences and cut down shrubs and trees using a scythe or an axe. Another sign that men and women were participating in this activity in different ways came with the perception of who is taken as the group leader. Even when girls and women participated, boys and men were responsible for the activity. In this way, boys began to participate in production processes that supported their family groups.

Gradually, we began to notice other differences in the way, for example, that men and women regard their work in the crop fields. Women value this shared work as a moment of family cohesion and interaction with men. By contrast, men associate land with the livelihood of their families, as well as

\footnotetext{
5 Mariz et al. (1982) refer to several forms of work organization used by the Xakriabá: unions (união), gatherings (ajuntamento), task forces (mutirão), and support (adjuntório). The union consists of a large single family, which takes responsibility for production in a collective crop field; there is no real spatial division, just a symbolic one. The head of the extended family organises, distributes, and coordinates work and receives a share of the final product. A gathering involves the exchange of labour among different families. It works on a rotating basis, as the crop workgroup moves through the fields of each family to complete the cycle. A gathering tends to be specific to a particular task, whether coivara, land clearing, planting, or harvesting. A task force involves a group that work collectively in the fields of a single family by request or invitation and being fed by the host family. Finally, 'support' involves the exchange of days between relatives and friends, to carry out small tasks that do not require a lot of manual labour. Among the Xakriabá, we were able to identify a strong union, gathering, and many examples of support, although we were not able to confirm that these classifications were still used.
}

Horizontes Antropológicos, Porto Alegre, ano 21, n. 44, p. 173-200, jul./dez. 2015 
with the political struggle to ensure the rights and identity of indigenous peoples (Teixeira, 2008). As pointed out by Santos, A. F. M. (1997), shared work in the community crop fields during the struggle to retain the land highlighted the symbolic importance of agricultural work among the Xakriabá people and, in particular, men's perception of the importance of this activity.

The task we selected for analysis involves using a scythe to work on the crops (bater foice). This activity includes clearing the land by cutting grass and small shrubs. Those undertaking this work must know how to handle a scythe, which is a very sharp tool made of steel, with a semi-circular curved blade attached to a long wooden handle (between $1 \mathrm{~m}$ and $1.20 \mathrm{~m}$ ). This tool allows the user to cut grass and bushes while remaining upright, in a slightly inclined position.

Using a scythe involves mastering a number of cutting techniques. By analysing some of the movements of Xakriabá boys engaged in clearing the land, we were able to identify and classify some specific techniques.

A) Casting the scythe over bushes diagonally from top to bottom and left to right (or right to left). This movement is short; the user raises the scythe to a height between his head and waist. The gesture resembles a mowing movement because the user pulls the scythe toward his own body (Figure 1). ${ }^{6}$

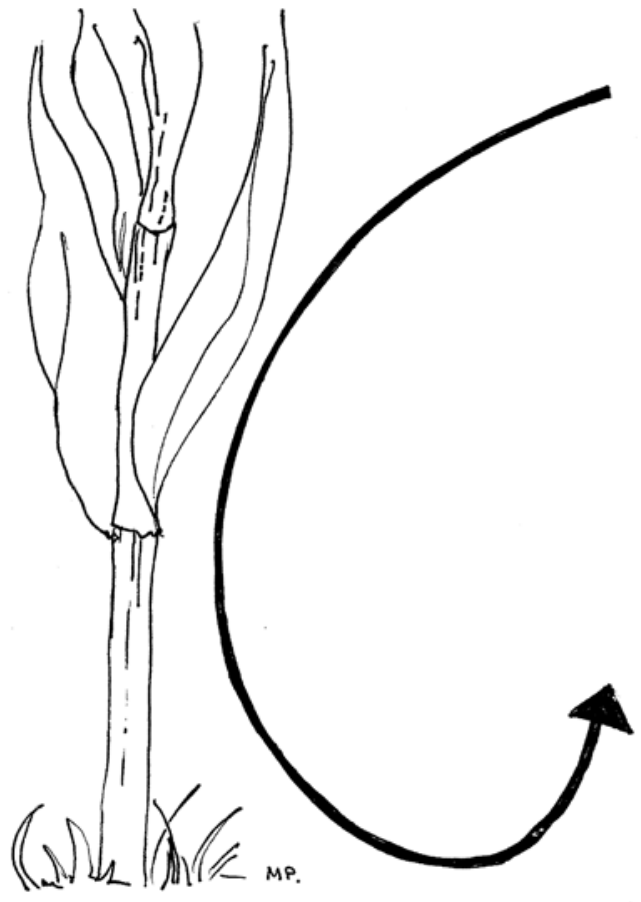

figure 1 .

6 All illustrations are made by Mônica Palhares. 
B) The pendulum and the uninterrupted movement. The user holds the scythe with both hands, with one hand in front and the other on the end of the handle. He then moves the tool from right to left, keeping it parallel to and very close to the ground, with the blade slightly inclined downward. When the scythe returns from the left to the right side, the user rotates the handle with his wrists to

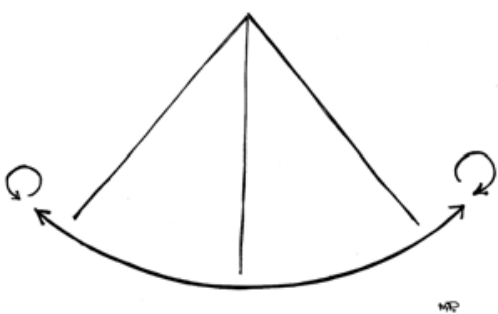

Figure 2. position the blade for cutting and performs the reverse movement (Figure 2).

Mr Servino captures an important part of this movement by demonstrating how to use the hands during the pendulous scythe movement. He shows how the hands change place; by putting one hand on top of the other, he demonstrates the importance of the wrist's rotary motion (Figure 3 ).
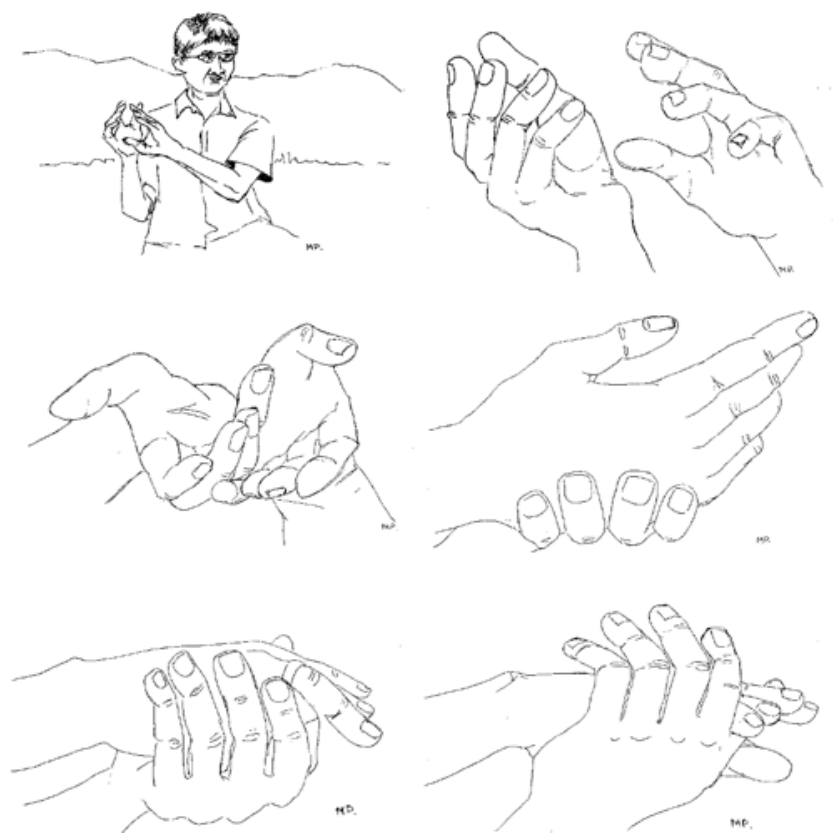

Figure 3. 
C) The blow used to cut a specific shrub: the user strikes the shrub diagonally from above, in order to cut through the main stem close to the soil. He raises the scythe in front of himself, holding his hands together almost at head height to deliver a single blow. This movement begins with the user standing directly in front of the shrub and holding the scythe in front of him with both hands; the tool tilts diagonally toward the side of the shrub he aims to hit. When performing this movement, the right hand tightly grasps the end of the handle, while the left hand slides down the handle, enabling the user to grasp the handle firmly and to strike a blow either far from or close to his own body at the right time (Figure 4).
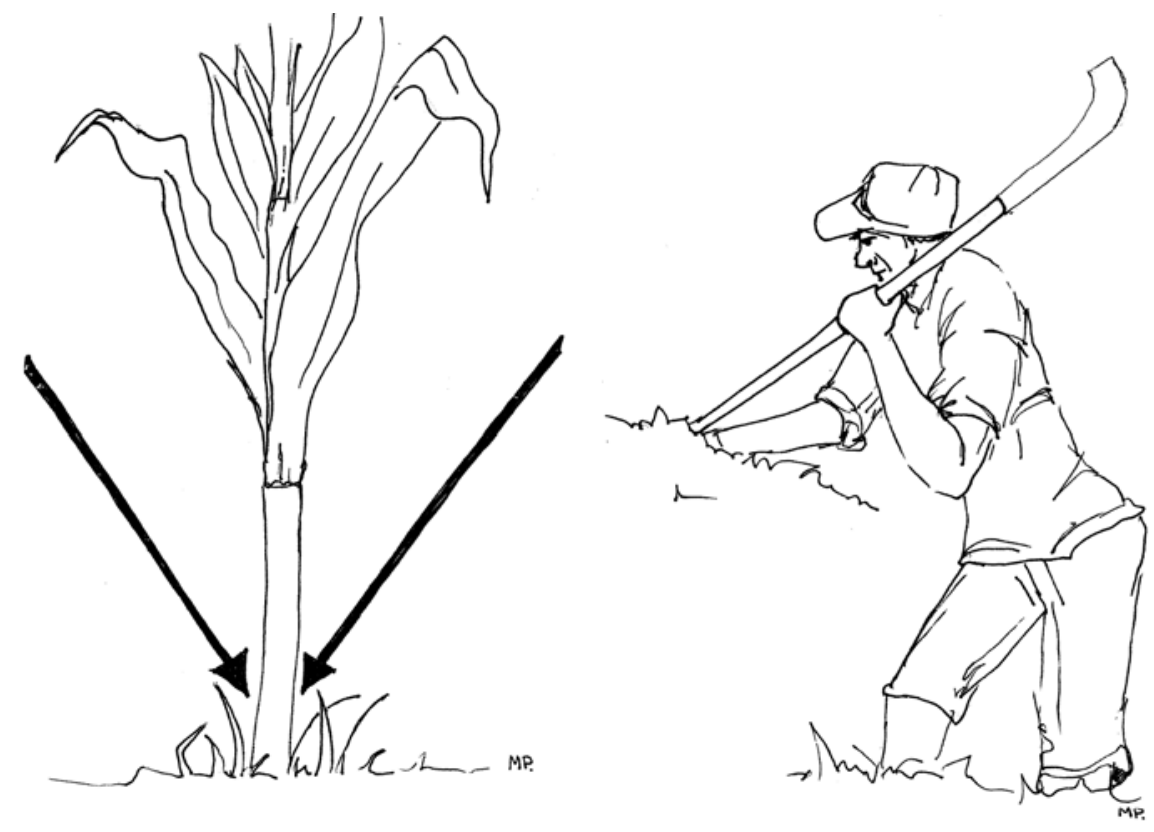

Figure 4.

D) Dragging the detached material. In this movement, weeds are pulled out of the soil and thrown behind the user of the scythe as he moves forward mowing, keeping his work area clear (Figure 5). 


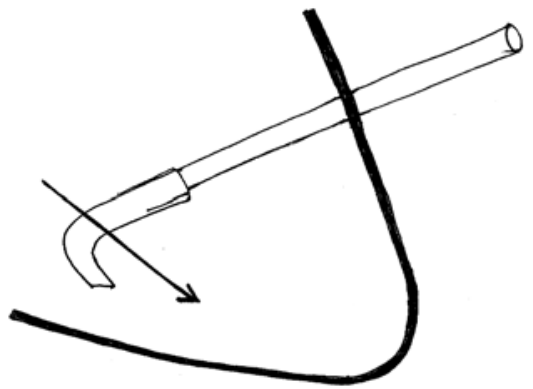

Figure 5.

Seen from a distance, the scything and weeding can seem like repetitive motions that could be performed for hours. However, by analysing these movements in relation to what Ingold (Ingold; Lucas, 2007, p. 288), following Lave, have called 'learning through doing and understanding in practice' - we may conclude that, far from being the mere repetition of a simple, reproduced gesture, these movements constitute a genuine skill (cf. Ingold, 2000, 2001). Adults show boys who are learning to weed and scythe what they should do and focus on (cf. Ingold, 2010). By paying close attention to adult techniques and movements, the boys learn to adjust their own movements, adopting and adapting the observed rhythm and action. While handling scythes, children and adults establish a dialogue with their bodies, the scythe, and the environment in which they handle the tool. Their eyes constantly scan the field, identifying and mapping the next section of land to be mowed. Perception and body movement improve as the grass is cut. It is interesting when the boys realise that something needs to be adjusted, such as a blade that has become dull, lopsided, or detached from the handle. In a seemingly repetitive gesture, these boys develop a readiness for action and a fluidity of movement that allows them to execute all of the steps involved in cutting, changing, and adapting their movements to various conditions. Seen from this point of view, every stroke is different from the previous one. The force used, the inclination of both the scythe and the body, the tight hold on the handle, as well as the results obtained guide decisions regarding the next stroke. It takes some time to arrive at this level of awareness, and the practitioner's performance shows the extent to which it has been achieved. For example, it takes time for a user to become familiar with his tool. The many factors involved in this process include the weight, thickness, and handle shape of the tool, as well as the adaptation of the user's hand to a particular tool (for example, by developing calluses). For this reason, each boy, from a very early age, chooses his own scythe once he has adjusted to it. 
When we compared the scything movements of boys and men, one particular experience clearly showed us how the observation skills and bodies of boys improved as they mowed with scythes. During research conducted between 2009 and 2010, we made some quick video recordings of a group using scythes to mow an area they intended to plant. This group consisted of two boys, aged 10 and 12 (Darley and Reginaldo), and two men: Mr Servino, the father of the boys, and his brother. Four years later, we returned to show our video to the boys, now 14 and 16 years old. The video greatly amused the spectators, who found the mess (zoada) made by the boys with their scythes very funny, as even Mr Servino admitted. I interpreted the expression zoada to mean 'disorder', 'random movements', 'noise', and 'confusion'. The boys themselves acknowledged that they had both changed significantly since the video. Watching it showed them how differently they now managed their scythes. It was clear to all of us that there was a difference between the movements of the boys and the men when handling scythes. The video also enabled us to define these differences more explicitly. The first difference involved the accuracy and speed of the gestures; the men's movements were firmer and more precise. They involved fewer gestures, and were relatively brief; in other words, the men cut grass with less effort. This became particularly clear when we compared the pendulous movement used in handling the scythe. When men carried out this movement, the strike practically ended with the cut, very close to the grass. When the boys attempted it, their strikes were more elastic, extending beyond the cut; the boys cast their scythes sideways, holding both hands at shoulder height (as if using a baseball bat or golf club). This allowed them to generate the force required to perform the reverse blow, which sometimes took longer to implement. As the sequence of images below illustrate, when Reginaldo made the pendulous movement, the scythe made a full circle around him. The movement started with the scythe resting on one shoulder, and finished on the opposite one. Reginaldo used much of his strength to keep the scythe in the air.

We may conclude that learning how to handle a scythe involves 'eliminating' or reducing the number of gestures. The user increasingly seeks precision, economy, and efficiency, as well as a more constant cadence and a concentrated strength when mowing or reaping. The boys perform more elaborate movements at a slower pace. They make the pendulous movement more often than the adults do. This may be because the stroke is only useful in terrain with few shrubs, as their father, Mr Servino explained (Figure 6). 

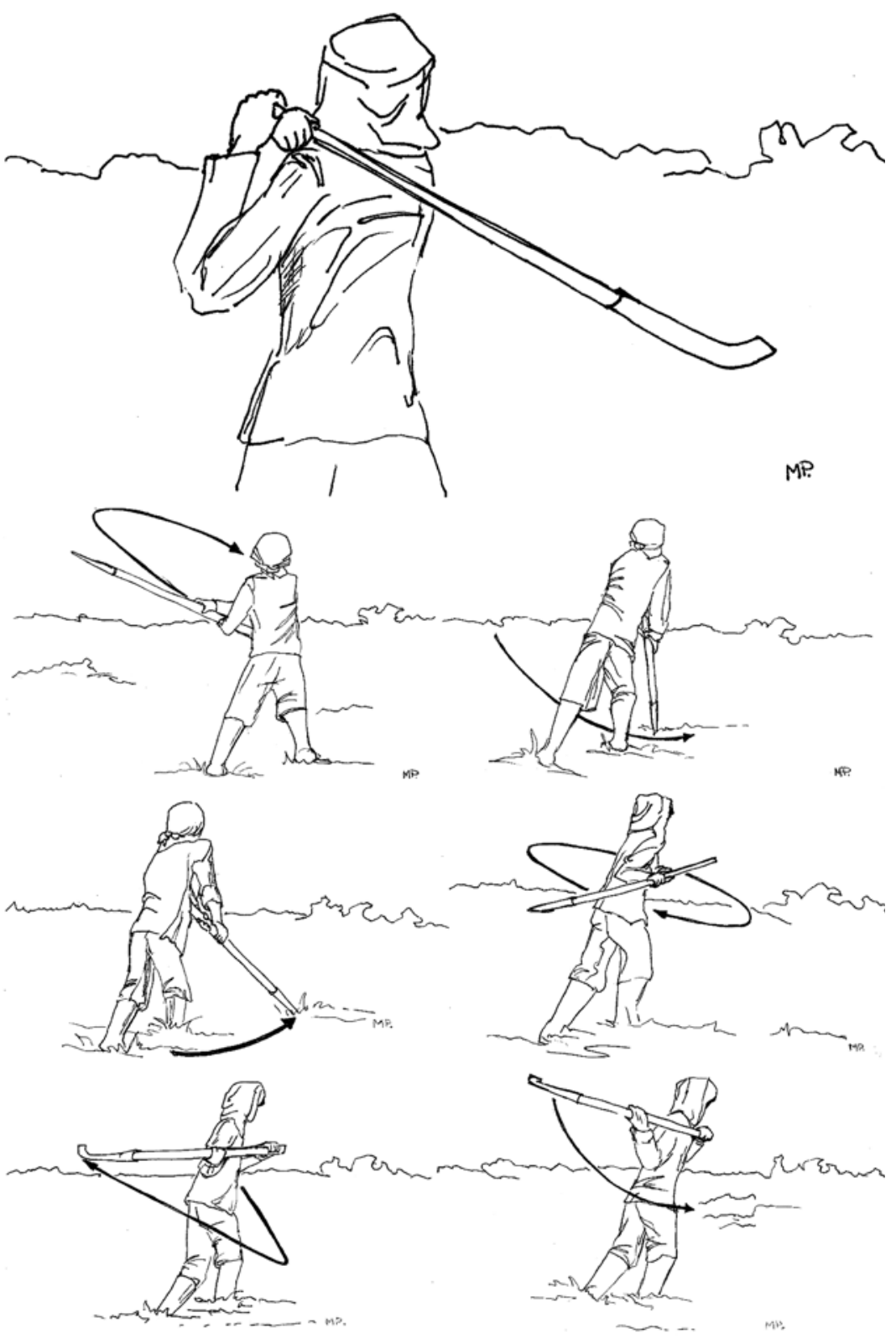

Figure 6 .

Horizontes Antropológicos, Porto Alegre, ano 21, n. 44, p. 173-200, jul./dez. 2015 
The adult men seek out harder to clear places with many shrubs, eliminating the need for this movement. The boys' physical effort is greater than the men's. However, the force they use cannot slash the grass with a single stroke. Instead, they are forced to interrupt the movement whenever their scythes hit bushes, and to raise the scythes again.

If we use this scene as an emblematic example, taking into account the description of the boys' chores, we may say that learning through model-based practice means producing a field of action, or movements, that is larger than the model itself. This larger field serves to adapt the practice performance to the practitioner's conditions. It is important to point out that the apprentice himself performs this adjustment, for example, by choosing a scythe or developing a personal way of handling it. The movements are wider and reflect body rhythms. The practitioner performs certain gestures more often and selects an area to work in.

By developing practice in accordance with a broader field of action, the learner ventures beyond that task, learning more than the specific task he will carry out. He also has many other lessons to prepare his body for handling the scythe. The learner adapts these lessons to the environment and his tool, while guided by a skilled practitioner with whom he interacts. To cite a possible epistemological principle, we may say that, faced with a task designed on a field of practice, which is available as a whole for the apprentice (cf. Lave; Wenger, 1991, p. 93), the apprentice himself provides the steps and adjustments necessary to carry out the activities. By doing so, he prepares himself to master the practice. The best way to learn is through practice immersion, with the techniques modelled by a skilled practitioner. However, learned techniques must be modulated, ${ }^{7}$ and somewhat expanded, by the apprentice.

This is an excellent way to study how people learn through practice immersion, offering interesting insights into how beginners learn. It also reveals significant aspects of the practice in question. The scythe is not adapted to the boys' body dimensions, but parents do sometimes produce smaller versions of the hoe, offering another approach to the development of learning through practice. Finally, we highlight two aspects of scything, beyond Xakriabá gender

\footnotetext{
7 The verb, 'to modulate' is generally used to refer to singing; it means to produce changes in a pattern or rhythm, or to sing according to theme variations. Metaphorically, we may say that the boys 'modulate' their use of the scythe.
} 
roles and individual development. Agricultural work shapes the bodies of the boys. The same activity that prepares the body for agricultural work builds and strengthens specific muscles that, in turn, influence their performance. This idea reflects the Xakriabá saying that boys need to grow and develop powerful muscles (pegar corpo, 'get body'). Once the boys begin labouring in the fields, adults become concerned about strengthening their bodies. Growing and developing in order to 'get body' (pegar corpo) may mean making the body strong, robust, and fit to work. However, a strong body does not automatically provide the skill needed to perform a task. Thus, we are talking about a body that strengthens itself by learning a skill; as well as a skill that develops itself from within the body, in a 'total field of relations,[...] in a richly structured environment' (Ingold, 2001, p. 21). Thus, the men say that developing strong muscles is just as necessary for boys learning to work in the crop fields (or, as Lave and Wenger say, becoming full participants) as knowing how to handle tools. At this stage, despite the intense learning they have been through, they still have not developed either sufficient strength or the physique required to handle every sort of field work, including scything and using an axe. At the same time, the men believe that this will only happen if the boys are allowed to keep working as they grow. Thus, the body does not develop merely with age, but during the course of an activity that leads to a skill.

For the Xakriabá, a healthy body is, in this sense, a body fit to work in the fields - resistant to bad weather conditions and sudden unexpected events. It is a body that strengthens itself and is aware of the effects of certain foods, on the one hand; it is also a body subject to diseases caused by entities that inhabit the territory (dead spirits, snakes, and spells). We believe there is a strong connection between the idea of 'getting body' (pegar corpo), working in the fields, and building a male identity among the Xakriabá. Men and boys share the same experiences. In addition, they see working on the land and retaining indigenous territory as important elements for building their own identities. Being a man means working in the fields and having a body developed for this purpose, as well as the required strength and technique to handle tools, master production skills, and, finally, being the person in charge for it.

The examples of roaming through several households and the crop fields, acquiring knowledge through these activities, and gaining an understanding of how activities are structured to ensure their participation, all of this illustrate the kind of sociability these children are involved in. As a first observation, we 
can see that childhood is a relational category because it links itself to other categories (gender, apprenticeship, age). According to the indigenous conception of childhood, the adult and child worlds are not separated; on the contrary, they are deeply interconnected (Cohn, 2000; Silva et al., 2002; Tassinari, 2007). By observing children's actions and their participation in their families and communities, one becomes convinced that the Xakriabá boys play a key role in preserving their group as they learn.

\section{Learning to hunt}

Although (in the recent past) hunting was a common practice among the Xakriabá people, it has decreased significantly today. The importance of hunting to the Xakriabá is recorded in Januário Cardoso’s official land donation document; it also features in the collective memory of this people, expressed in sung verses transmitted from one generation to the other: 'the Gerais fields for honeydew and hunting ${ }^{8}$ are cited in the official documents as justification for donating certain parts of the territory.

Hunting offered boys and men a different way to roam through the territory and to appropriate space. It enabled them, for example, to move through areas (such as the woods) that were outside their daily routines, thereby articulating different kinds of knowledge, such as the ability to read animal signs and tracks. Even if the woods was regularly used for villagers activities, the fact that boys often hunted in the woods turned it into a territory belonging to the hunters; it became for them a privileged place for learning.

Hunting - and learning to hunt - was an activity carried out both by individual boys and by groups of boys and youngsters of different ages through pilotagens (hunts using small balls made with dried clay called pilotas), and through hunting with men, who could hunt either alone or in company. One young man with a great knowledge of hunting was Deda, a culture teacher at the Xakriabá Indigenous School. He described learning to hunt at a very early age with his father and especially with his uncle, João de Prisca. Very often,

8 For this I give land/ so indigenous people can live in it [...] I give a bountiful land for indigenous people to live in:/ the mission for home/, the marsh for work,/ the Gerais fields for honeydew and hunting/ and the river banks for fishing'. Extracts from the music sung by elderly indigenous people collected by Alceu Cotia Mariz et al. (1982).

Horizontes Antropológicos, Porto Alegre, ano 21, n. 44, p. 173-200, jul./dez. 2015 
Deda would show his uncle the lairs of forest animals. As soon as he spotted an animal, he would alert his uncle and they would both go out to hunt it. When they returned with their catch, his uncle generally shared the meat with him.

Hunting implied mastering different elements and being able to act collectively. Hunters used rifles and pistols as weapons, but are also reported to have used scythes, bows and arrows, and slingshots (in the form of a bow that shoots clay balls - pilotas - instead of arrows). They preferred to hunt at night, and usually carried a can of cow manure and oil to make smoke and drive the insects away. They also hunted in the dark, with some carrying lanterns. Silence was crucial for the enterprise. When hunting together, everybody had to remain silent and to communicate through signs. To find and chase their quarry, one member of the group had to be able to read the animal's tracks by examining its footprints and the way it moved; experts would explain these traces to the novices. Even wounded, an animal could run for a long time before dying. However, the pattern of its footsteps would gradually change, leaving new marks on the trail. It was very important to be able to understand these changes because they told the hunter whether or not he should continue to pursue the animal.

Hunting required patience and planning. Initial information about the animal being tracked was very important, providing the hunter with data regarding size, height, weight, and ability to fly. It showed whether the animal was a cat, a fox, a white-lipped peccary, a deer, a collared peccary, a black and white tegu, a tinamou, a rock cavy, an armadillo, a magpie, a giant anteater, a collared anteater, or a rabbit... the list of possibilities was quite long. For each type of animal, a specific trap or snare was built: these included clap traps, noose traps, nets, box or cage traps, and deadfalls. In some cases, animals that came into range were killed or trapped without the hunter needing to be present. In other situations, however, the hunter had to remain vigilant and to set up a cage trap on a treetop, near where the animal came for food, as in the case of deer and giant anteaters.

For hunts that required chasing and cornering the quarry, hunters usually relied on the help of dogs. Hunters also wore appropriate clothes for these hunts, usually the same ones they wore to work in the fields. They avoided clean clothes because animals would be able to sense their presence through the smell.

Omens also had an impact on hunting. Before starting, a hunter would look for signs indicating whether the venture would be successful or not. Interestingly, all of the signs we recorded were considered bad omens. For

Horizontes Antropológicos, Porto Alegre, ano 21, n. 44, p. 173-200, jul./dez. 2015 
example, if a weapon failed three times in a row, it was a clear sign that the hunter should head back home because he would not be able to catch anything. The same was true if a frog or fox crossed his path during the hunt. Once such signs were detected, the hunter asked for permission to enter the forest, and for protection against dangers such as the snakes' spying (espiação das cobras). It was common for hunters to carry garlic cloves or some tobacco in their pockets.

According to many people in the region, $\mathrm{Mr}$ João de Prisca was a terrific hunter who continues to go out hunting to this day. When he was younger, his cousin-brother used to be his most frequent hunting partner, but nowadays, $\mathrm{Mr}$ Prisca hunts with his grandchildren. Mr João chooses small boys who have not yet learned to hunt. Despite their inexperience, these boys have a key role in the venture because they provide Mr João with one of the senses he can no longer rely on: hearing. Thus, the children become part of a situation of mutual dependence. Although Mr João is very experienced, he is not able to hunt without the help of his grandson, even if the experience is mainly a learning opportunity for the boy.

When Deda learned to hunt with his uncle, his participation was crucial, even though he was just a beginner, learning how to find animal layers (camas) in the woods. Now, we see Mr João relying on his grandchildren's ability to identify various woods sounds during the hunt. An important feature of learning to hunt was the adults' acknowledgement of the children's skills. This would be important during a real hunt, where children would share some moments of peripheral participation and others of active participation (Lave; Wenger, 1991), during which they could actively contribute to making the hunt succeed. Learning to hunt and to hunt effectively were treated as coincident practices - there was no moment exclusively prepared or dedicated to learning.

Mr João de Prisca’s grandchildren, Reginaldo and Darley, learned to hunt with him. According to their report, they learned to hunt with their grandfather by accompanying him on his hunts. When their grandfather thought they had learned enough, he asked them to take on his role and go out hunting with a younger and less experienced boy. When they returned, the grandfather asked a few questions about their hunting techniques and procedures. At this point, he decided that both were ready and free to hunt on their own.

In addition to following adults, boys experience many other hunting situations that promote learning; these include pilotagens (shooting clay balls with slingshots) and hunting with traps. These two ways of hunting differ from

Horizontes Antropológicos, Porto Alegre, ano 21, n. 44, p. 173-200, jul./dez. 2015 
situations in which boys accompany adults; here the boys hunt with their peers. These hunts can be interpreted as a weekend activity (hunting with traps), as well as a diversion from daily chores (shooting clay balls with slingshots).

It has been interesting to recognise and acknowledge the woods as the boys' hunting territory. It was already a territory in which new ways of moving and perceiving were established. One of us, being a man, was able to follow the boys; he did not know how to move in this new space, although the boys were able to do it quite safely. He therefore asked them to guide him. The boys led him through the woods, told him where he should go, and warned him whenever he got too close to thorns and nettles, as well as holes and burrows, just as they would have guided young boys. When boys walk in the woods, they pay such close attention to their surroundings that their gaze, to quote Deleuze (L’Abécédaire de Gilles Deleuze, 1996), could be classified as an 'animal gaze' or even the gaze of a 'watchful animal'. The boys' senses became sharper, aware of sounds and movements around them. Thus, as they walked together, they identified the presence of animals moving around in their shared space.

The following account, rewritten from our field notes, of a hunt conducted by six boys and youngers between the ages of 12 and 22 illustrates this coordinated movement among skilled practitioners and apprentices:

Despite being close to the houses of the village and between fields intersected by roads, there were continuous woods tracts, where we could walk for a long time without leaving the woods. As a 12-year-old boy was present, it was possible to observe his training during the hunt, guided by an older cousin of 16 . The guys spread silently over the ground, in search of birds. Eyes turned to the treetops watching the movement of birds. The movement of the hunting boys in the woods was quiet, cautious, bodies bent forward and with slingshots and slings (or slingshots) loaded with their pilota. They did not use the path made by the tracks. The boys went deep into the woods among the trees, treading softly on the ground covered with dry leaves, without making a sound, and dodging the vines, bushes, dry branches, and fallen trees they encountered along the way. Even without tracks, each one walked in the same direction as the rest of the group, despite being separated in the woods, at a distance of about 50 meters from each other. During the hunt, we observed the guidance one young hunter gave to his twelve-year-old cousin. Dái instructed Tiago on where to wait and walk, and he responded immediately. Even without a sling, Tiago followed the group and from time to time asked one of his cousins for permission to shoot on what was allowed to shoot. Just like the little boy, our researcher received guidance from the hunters on how to move and behave. 
One question remains, however. Why do the Xakriabá continue to hunt, when most people assume that hunting is no longer possible, given reduced hunting areas, decreased animal populations, constant inspections by the Ibama Federal Agency, uncertainty about the future, and the group's changed diet? The Xakriabá now include more and more processed food products in their diet, especially meat derived from cattle and other domestic animals such as chickens and pigs.

Despite this apparent paradox, the way the Xakriabá organise their hunting expeditions seems emblematic to us. Taking into account the actions and patterns that enable beginners to join older and more experienced boys and trained hunters in the hunt, we can outline other principles that this articulation of the practice expresses.

It is important to point out two key aspects of this practice: first, it is possible to participate in a hunt without mastering the skills completely, because the hunt is organised in such a way that the presence of beginners is expected, and eventually required. This is possible because the action develops collectively, both in its modus operandi and in its results. Second, although hunting is an activity with a precise focus - to find the quarry and capture it - it is necessary for participants to develop a high degree of multi-focused attention (given the many agents involved in the practice). Participants must pay close attention, never losing sight of the situation but remaining sensitive and responsive to their surroundings. This balance, through which participants keep their focus while staying in step with each other, protects hunters from inverting the situation, and themselves becoming prey.

\section{Modelling, modulating, moulding: learning through practice and from practitioners}

The example of bater foice (using a scythe to harvest grain or cut grass) and the way boys develop this skill highlights the necessary adjustments involved in attempting to learn from a model set by someone else. Ingold (2001, p. 21) called attention to the fact that, even in seemingly repetitive gestures, such as those made by a blacksmith forging iron, movements are never the same. In addition, fine-tuning every strike should be both a ready and improvised response to conditions that vary each time. We would argue that, both 
for skilled practitioners and for beginners - for different reasons and using different resources - repetitive movement within a given practice always implies an improvisation that becomes part of the response as time goes by.

It is worth mentioning the ability to improvise when analysing and imitating a model. This ability enables beginners to achieve what they set out to do in whatever conditions they encounter.

Copying or imitation is not a simple, mechanical process of replication [...] but entails a complex and on-going alignment of observation of the model with action in the world. In this alignment lies the work of improvisation. (Ingold; Hallam, 2007, p. 5).

Ingold argues that improvisation is generative; in other words, improvisation itself is implicitly responsible for the transforming the character of the model. This makes a practice evolve and change, in addition to repeating itself, from generation to generation, as well as from practitioner to practitioner.

The hunting expeditions led by the grandfather (who no longer has enough hearing to hunt alone) accompanied by his grandson (who does not yet have enough trained auditory acuity to hunt alone) reveals a specific practice articulation that creates the conditions for its own continuity. Associated with this aspect (which could mistakenly be considered circumstantial), we have the prescription that a boy can only become a fully skilled hunter (ready to hunt alone) when he is able to guide someone less experienced. This suggests that the ability to guide or assist another is a criterion consciously used to define a skilled practitioner. This ability to place oneself alternately in both positions - as the guide and the guided - is experienced by boys in ascending age groups with different levels of skill. We would argue that, with coparticipation in a practice (Lave), comes a certain degree of co-responsibility (Gomes; Silva; Pereira, 2013), although this does not imply that these positions are held permanently. In other words, learning and enabling others to learn are possibilities that open new alternatives, without resorting to the idea of teaching. ${ }^{9}$

\footnotetext{
9 A comment about this matter: not all languages have terms that distinguish learning from teaching. In Romané (the language of the gypsies), the verb ‘to teach' does not exist, nor anything close to it. There is only one term, which can be translated as 'to learn'; this can result in a curious inflection when a child in school asks someone 'to make her learn', but does not ask to be taught (cf. Gomes, 1998).
} 
This concept seems particularly relevant when we consider that the idea of promoting learning among peers has been part of the history of Xakriabá schooling since it was introduced by one of the community's 'first teachers', Ms Joana. Ms Joana began working with the Xakriabá even before there were indigenous schools (cf. Gomes, 2006). In order to be officially recognised as a teacher, Ms Joana completed the indigenous teachers' training course along with the first group trained at Minas Gerais. However, she refused to go to college afterwards, preferring to remain active in the village. She was elected to work with children in pre-school classes ( 3 to 5 years old) because the community trusted her and appreciated her way of welcoming students. When teaching the children reading, she used to keep her best students in the first grade so that they could help beginners in their learning process. This system was called 'failure of the best' when analysed by our research group. Ms Joana showed that she understood very well what schooling practice meant. She used her consolidated authority as a teacher to intervene in this practice, reorienting it to promote what she considered necessary, ensuring that all students received enough attention. Such a change in the rules of the game calls to mind Levi-Strauss's description of Bororo's way of playing soccer. The group used to change the playing time to ensure that the result would be a tie. The ritual of schooling, just like this sports ritual, presents a disjunctive function. It acknowledges, according to social rules, the legitimised production of winners and losers, as well as the first group's lack of commitment to the second. This feature was altered to produce a collective result, just as the way of learning also became collective.

We would argue that elements, which might in other contexts represent 'failure', such as an elderly practitioner becoming too old for his activity or an inexperienced beginner, here reveal the intrinsic forms of participation related to particular practices. This articulation looks beyond the position of only individuals, and at the same time avoiding practices to be seen as something beyond them.

In addition, the focused attention required for hunting seems to be similar to what has been identified as 'keen observation' (Rogoff et al., 2003), a particular way of guiding one's own attention, which is characteristic of children from communities in which children participate in adult practices. We still have much more to learn from the way Xakriabá boys are prepared to hunt. 
Producing ethnographies that describe these processes in detail can generate a wide range of references to ways of learning in various context practices where learning is somehow assured. In our view, this wide range of references should guide the promotion of new learning, which always involves new practices. As Lave confirms, 'learning by doing' is not just an approach to learning - all learning is situated. This is why she insists that it is necessary to decentralise the idea of learning and to focus on practices and practitioners experiencing constant change (Lave, 2013).

Lave (2011) reaffirms the need to review implicit ideas that shape the notion of learning, many of which derive from the school configuration. Historically, this configuration has been the source of cognition, action, and thought studies. School guidelines are more pronounced and visible in certain research approaches (as in the case of psychological tests). However, they are not restricted to this universe and have a much greater impact, as Herzfeld (2012, p. 707) has explained:

Jean Lave, in what she experienced as a decidedly halting process of enlightenment, came to find positivistic experimental methods empirically unsustainable and their intellectual roots stubbornly persistent. Her progressive rejection of the key dichotomy between formal and informal systems resonates with current anthropological research in arenas as diverse as settlement types, economic systems, and religious practices.

We accept the need to move beyond the formal/informal dichotomy when analysing learning, as well as to move beyond the dichotomous opposition between educated and non-educated people. School is also the source of specific practices that also need to be learned, as H. Mehan demonstrated in his wellknown book Learning Lessons. Instead of producing students with 'learning difficulties', these practices produce unwanted learning (McDermott, 1996; McDermott; Varenne, 1995). Focusing on careful and detailed descriptions of practices, and on the way they are articulated, can help us to review what is perceived as learning. [However, this is something that cannot be topicalised (fully perceived) by those who practice it. This is another argument for decentralising the idea of learning, as Lave (2013) recommends.]

Analysing in detail the everyday practices of the Xakriabá boys and the approaches to learning they reveal illustrates the value of a learning 
ethnography. This ethnography can be understood as attentive and capable of viewing learning as a constitutive part of social practices. ${ }^{10}$

Still referring to Lave, Herzfeld (2012, p. 707) comments:

The core of her argument is that theory is itself a form of practice and must be understood contextually through its embodiment in ethnographic practice, much as we should also view contextually such apparently ratiocinative and abstract activities as mathematical calculation.

$[\ldots]$

Beyond strictly educational questions, Lave's argument implicitly militates against the political malaise of audit culture and the attendant proliferation of so-called knowledge centres as well as the mindless deskilling of factory workers, although she does not explore these larger implications here.

If Herzfeld's assertion alerts us to practices that produce disqualification, something common in a modern world marked by capitalist organization, it also makes us look for and question practice domains in which the ability to produce learning takes place effectively. This can be incisive and ubiquitous - like soccer in Brazil, archery among indigenous communities that live by hunting, and agricultural production in family farming communities that control species and production methods in their own biomes.

We have much to learn from boys and girls who know how to model and modulate their activities to learn and allow others to learn through freely participating in various practices, which also mould their bodies. In other words, our theoretical learning practice (Herzfeld) - which can begin, as suggested by Lave, with the exercise of 'suspension' regarding knowledge and learning concepts - still has a long way to go.

${ }^{10}$ See Gomes and Faria (in press).

Horizontes Antropológicos, Porto Alegre, ano 21, n. 44, p. 173-200, jul./dez. 2015 


\section{References}

L’ABÉCÉDAIRE DE GILLES DELEUZE. Réalisation: Pierre-André Boutang. Paris: Éditions Montparnasse, 1996. 3 DVD (464 min).

COHN, C. A criança indígena: a concepção xikrin de infância e aprendizado. 2000. Dissertação (Mestrado em Antropologia)-Faculdade de Filosofia, Letras e Ciências Humanas, Universidade de São Paulo, São Paulo, 2000.

COHN, C.; TASSINARI, A. M. I. Opening to the other: schooling among the Karipuna and Mebengokré-Xikrin of Brazil. Anthropology \& Education Quarterly, Arlington, n. 40, p. 150-169, 2009.

CORREA, E. N. História e modos de caçar: uma forma de compreender a cosmologia xakriabá. 2013. Trabalho de Conclusão de Curso (Formação Intercultural de Educadores Indígenas)-Faculdade de Educação, Universidade Federal de Minas Gerais, Belo Horizonte, 2013.

ESCOBAR, S. A. Projetos sociais do povo indígena xakriabá e a participação dos sujeitos: entre o desenho na mente, a tinta no papel e a mão na massa. 2012. Tese (Doutorado em Educação)-Faculdade de Educação, Universidade Federal de Minas Gerais, Belo Horizonte, 2012.

GOLDMAN, M. Alteridade e experiência: antropologia e teoria etnográfica. Etnográfica, Lisboa, v. 10, n. 1, p. 161-173, 2006.

GOMES, A. M. R. “Vegna che ta fago scriver”: etnografia della scolarizzazione in una comunità di Sinti. Roma: CISU, 1998.

GOMES, A. M. R. O processo de escolarização dos Xacriabá: história local e os rumos da proposta de educação escolar diferenciada. In: SOARES, L.; GIOVANETTI, M. A.; GOMES, N. L. (Org.). Diálogos na educação de jovens e adultos. Belo Horizonte: Autêntica, 2006. p. 243-254.

GOMES, A. M. R.; FARIA, E. Etnografia e aprendizagem na prática: explorando caminhos a partir do futebol brasileiro. In press. 
GOMES, A. M. R.; MONTE-MÓR, R. L. M. Conhecendo a economia xakriabá. Belo Horizonte: FaE/FACE-Cedeplar/UFMG, 2005. Relatório de Pesquisa.

GOMES, A. M. R.; SILVA, R. C.; PEREIRA, V. M. Aprendizagens e vida cotidiana entre meninos e meninas xakriabá. 2013. Paper presented. XIII Simpósio Interamericano de Etnografia de la Educación, Los Angeles, UCLA, September 18-20, 2013.

HERZFELD, M. Apprenticeship in Critical Ethnographic Practice, Book review. American Anthropologist, Arlington, v. 114, n. 4, p. 707-708, Dec. 2012.

INGOLD, T. The perception of the environment: essays on livelihood, dwelling and skill. London: Routledge, 2000.

INGOLD, T. Beyond art and technology: the Anthropology of skill. In: SCHIFFER, M. B. Anthropological perspectives on technology. Albuquerque: University of New Mexico Press, 2001. p. 17-31.

INGOLD, T. Da transmissão de representações à educação da atenção. Educação, Porto Alegre, v. 33, n. 1, p. 6-25, jan./abr. 2010.

INGOLD, T.; HALLAM, E. (Ed.). Creativity and cultural improvisation. New York: Berg, 2007. (ASA Monographs 44).

INGOLD, T.; LUCAS, R. The 4 A's (Anthropology, Archaeology, Art and Architecture): reflections on a teaching and learning experience. In: HARRIS, M. (Ed.). Ways of knowing: new approaches in the anthropology of experience and learning. Oxford: Berghahn Books, 2007. p. 287-306.

LAVE, J. Apprenticeship in critical ethnographic practice. Chicago: The University of Chicago Press, 2011.

LAVE, J. Situated learning in a long-term perspective. 2013. Conferência apresentada. Quarta na Pós, Faculdade de Educação, Universidade Federal de Minas Gerais, Belo Horizonte, maio 2013. 
LAVE, J.; WENGER, E. Situated learning: legitimate peripheral participation. New York: Cambridge University Press, 1991.

MARIZ, A. C. et al. Relatório de viagem à área indígena xakriabá. Brasília: Funai, 1982.

MCDERMOTT, R. The acquisition of a child by a learning disability. In: CHAIKLIN, S.; LAVE, J. (Ed.). Understanding practice: perspectives on activity and context. New York: Cambridge University Press, 1996. p. 269-305.

MCDERMOTT, R.; VARENNE, H. Culture as disability, Anthropology \& Education Quarterly, Arlington, n. 26, p. 323-348, 1995.

PENA, J. L. Perfil sanitário, indicadores demográficos e saúde ambiental após a implantação do distrito sanitário especial indígena: o caso dos Xakriabá em Minas Gerais. 2004. Dissertação (Mestrado em Saneamento, Meio Ambiente e Recursos Hídricos)-Escola de Engenharia, Universidade Federal de Minas Gerais, Belo Horizonte, 2004.

PEREIRA, V. M. A circulação da cultura na escola indígena xakriabá. 2013. Tese (Doutorado em Educação)-Faculdade de Educação, Universidade Federal de Minas Gerais, Belo Horizonte, 2013.

ROGOFF, B. et al. Firsthand learning through intent participation. Annual Review of Psychology, Palo Alto, n. 54, p. 175-203, 2003.

SANTOS, A. F. M. Dos caboclos do Sr. São João à terra indígena xakriabá: as circunstâncias da formação de um povo: um estudo sobre a formação de fronteiras. 1997. Dissertação (Mestrado em Antropologia)-Instituto de Ciências Sociais, Universidade de Brasília, Brasília, 1997.

SANTOS, R. B. C. A cultura, o segredo e o índio: diferença e cosmologia entre os Xakriabá de São João das Missões/MG. 2010. Dissertação (Mestrado em Antropologia)-Faculdade de Filosofia e Ciências Humanas, Universidade Federal de Minas Gerais, Belo Horizonte, 2010. 
SANTOS, R. M. dos. $O$ Gê dos gerais: elementos de cartografia para a etnohistória do planalto central: contribuição à antropogeografia do cerrado. 2013. Dissertação (Mestrado Profissional em Desenvolvimento Sustentável)Universidade de Brasília, Brasilia, 2013.

SILVA, A. L. et al. Crianças indígenas: ensaios antropológicos. São Paulo: Global, 2002.

SILVA, R. C. Circulando com os meninos: infância, participação e aprendizagens de meninos indígenas Xacriabá. 2011. Tese (Doutorado em Educação)-Faculdade de Educação, Universidade Federal de Minas Gerais, Belo Horizonte, 2011.

TASSINARI, A. Concepções indígenas de infância no Brasil. Revista Tellus, Campo Grande, ano 7, n. 13, p. 11-25, out. 2007.

TEIXEIRA, I. A. V. Conhecendo a vida das mulheres xakriabá: gênero e participação. 2008. Dissertação (Mestrado em Educação)-Faculdade de Educação, Universidade Federal de Minas Gerais, Belo Horizonte, 2008.

WEBER, I. Um copo de cultura: os Huni Kuin (Kaxinawá) do Rio Humaitá e a escola. Rio Branco: Editora da Universidade Federal do Acre: Núcleo de Transformações Indígenas (NuTI), 2006. 